\title{
PELATIHAN ANALISIS KELAYAKAN USAHA KULINER MAKANAN RINGAN DI DESA TATAH PEMANGKIH LAUT KABUPATEN BANJAR
}

\author{
Basuki, Rahmi Widyanti, Susiladewi \\ Magister Manajemen, Program Pascasarjana, Universitas Islam Kalimantan \\ E-mail : msibasukidr@gmail.com
}

\begin{abstract}
The business opportunity of culinary business is very large because currently there are still promised who do second food while the demand for cookies along with awareness of people who are increasing in choosing healthy and second food products. The people who work as farmer will to expand its business by increasing their well being in business sector. Before running the plan, this community conducted a business feasibility study to be able to decide whether the culinary business plan is feasible or not to be implemented. Based on the results of activity on non-financial aspects of market aspects, marketing aspects, technical aspects and technology, aspects of management and human resources and environmental aspects this business feasible to be implemented.
\end{abstract}

Keywords : Feasibility studies, culinary bussiness, non financial aspect, financial aspect

\section{PENDAHULUAN}

Konsumsi makanan diperkirakan akan terus tumbuh di masa depan, dan kawasan Asia memainkan peran besar di dalamnya, kendati ekonomi yang melemah akibat pandemic covid 19 akan membatasi pertumbuhannya. Faktorfaktor yang memengaruhi pertumbuhan konsumsi makanan total adalah perubahan jumlah populasi, pertumbuhan pendapatan riil, harga bahan pokok yang relatif lebih murah dibanding bahan lain, dan perubahan preferensi diet masyarakat.

Pertumbuhan jumlah penduduk di Kalimantan Selatan terus mengalami kenaikan yang berakibat pada bertambahnya permintaan terhadap pangan baik makanan pokok maupun makanan ringan.

Peluang bisnis usaha kuliner makanan ringan sangat besar karena pengusaha yang memproduksi makanan ringan ini dapat memasarkan produknya tanpa harus bersaing dengan pengusaha lainnya sebab dapat membedakan varian produknya (Ibrahim Jacob, 2013).

Permasalahan yang dihadapi pengusaha makanan ringan ini adalah bagaimana menyusun suatu analisis usaha yang dapat dianggap layak dan menguntungkan di masa yang akan datang.

Analisis Kelayakan Bisnis adalah 
sesuatu kegiatan yang dilakukan pesaing.

perusahaan untuk menilai kelayakan

Freddy Rangkuti

(2012)

bisnis yang dijalankan untuk

menjelaskan Aspek teknis dalam Studi

mewujudkan laba perusahaan. (Ibrahim

Jacob, 2013). Studi kelayakan berperan

sebagai langkah pertimbangan untuk

menentukan apakah bisnis yang akan

dijalankan layak atau tidak.

Menurut Freddy Rangkuti (2012) aspek pasar dalam studi kelayakan bisnis dan investasi membahas besarnya permintaan, penawaran dan harga. Permintaan dan penawaran dilakukan dengan menggunakan metode proyeksi selama beberapa tahun kedepan. Tujuannya adalah untuk mengetahui seberapa besar tingkat penyerapan pasar, sehingga tidak terjadi kelebihan produksi yang dapat menurunkan harga. Tingkat harga juga harus dibandingkan dengan komoditas sejenis, sehingga pelanggan tetap bertahan pada pembelian produknya. Suliyanto (2010) menjelaskan bahwa aspek pemasaran bertujuan untuk mengetahui cara atau strategi agar produk yang dihasilkan dapat sampai ke konsumen dengan lebih efisien dibandingkan dengan pesaing. Aspek pemasaran menganalisis apakah produk yang dihasilkan dapat memberikan nilai lebih tinggi kepada pelanggan dibandingkan dengan produk Kelayakan Bisnis membahas hal-hal yang langsung berhubungan dengan operasional usaha, seperti kapasitas produksi, teknologi yang digunakan, skala produksi, proses produksi, lokasi, tata letak, , penjadwalan serta pengaturan tingkat persediaan.

Husein Umar (2013) menjelaskan studi aspek manajemen dilaksanakan dua macam. Pertama, manajemen saat pembangunan proyek bisnis. Kedua, manajemen saat bisnis dijalankan secara rutin. Sedangkan dalam aspek sumber daya manusia dibagi ke dalam dua bagian. Pertama, peran SDM dalam pembangunan proyek bisnis. Kedua, peran mereka dalam operasional rutin bisnis setelah dibangun.

Menurut Suliyanto (2010 ) aspek lingkungan menganalisis kesesuaian lingkungan sekitar (baik lingkungan operasional, lingkungan dekat dan lingkungan jauh) dengan ide bisnis yang akan dijalankan. Dalam aspek ini dampak bisnis bagi lingkungan juga di analisis. Lingkungan mempunyai pengertian yang snagat luas sehingga analisis aspek lingkungan dalam studi kelayakan bisnis dapat dibagi menjadi beberapa ruang 
lingkup. Beberapa ruang lingkup yang terdapat dalam lingkungan bisnis adalah lingkungan operasional, lingkungan industri dan lingkungan jauh.

Aspek keuangan pada umumnya merupakan aspek yang paling akhir disusun dalam sebuah penyusunan studi kelayakan bisnis. Hal ini karena kajian dalam keuangan memerlukan informasi yang berkaitan dengan aspek-aspek sebelumnya. Suliyanto (2010) menyatakan bisnis yang berorientasi keuntungan maupun yang tidak berorientasi keuntungan harus tetap memperhatikan aspek keuangan sebelum menjalankan bisnis.

Freddy Rangkuti (2012) menyatakan metode yang biasa digunakan dalam analisis keuangan studi kelayakan bisnis dan investasi adalah Payback Period $(P P)$, Net Present Value (NPV), dan Internal Rate of Return (IRR).

Tujuan dari analisis kelayakan usaha ini adalah untuk mengetahui apakah usaha kuliner makanan ringan ini layak dijalankan atau tidak. Analisis kelayakan usaha ini akan mempertimbangkan dua aspek yaitu aspek non finansial dan aspek financial.

\section{KHALAYAK SASARAN}

Dalam pelatihan ini mitra sasarannya adalah pengusaha kuliner makanan ringan baik sudah menjalankan usaha maupun yang baru akan memulainya di Desa Kelurahan Tatah Pamangkih Kabupaten Banjar.

\section{METODE}

Pelatihan ini dilaksanakan sebagai bagian dari Pemberdayaan Pada Masyarakat dilakukan dengan memberikan ceramah dan dialog interaktif untuk meningkatkan pengetahuan serta pemberian keterampilan berupa menyusun analisis usaha.

Metode yang digunakan dalam pengabdian ini melalui beberapa tahapan yaitu :

1. Tahap observasi kepada kelompok masyarakat yang akan dijadikan khalayak sasaran yaitu kelompok ibuibu petani yang sudah dan baru memulai usaha kuliner.

2. Tahap pelaksanan kegiatan adalah melakukan kegiatan pelatihan dengan mengikutsertakan partisipasi aktif peserta, pemberian keterampilan membuat menganalisis usaha kuliner yang nantinya di pasarkan. 
3. Tahap evaluasi pelaksanaan yaitu dengan melakukan pengukuran tingkat keberhasilan dari kegiatan pemberdayaan kepada masyarakat dengan melihat jumlah respon dan tingkat keterampilan khalayak dalam menyusus analisis usaha kuliner makanan ringan.

\section{PEMBAHASAN}

Pada kegiatan pelatihan ini peserta menunjukkan minat yang besar yang terlihat dari semangat para peserta. Pertanyaan yang diajukan para peserta berkenaan dengan pengetahuan tentang analisis usaha, faktor-faktor apa saja yang harus dipertimbangkan. Sebagian besar peserta $(75 \%)$ memilih belum mengetahui tentang analisis usaha ini.

Hal ini memerlukan pendampingan secara terus menerus dalam upaya mengukur seberapa jauh peserta memahami faktor-faktor yang harus dianalisis.

Dalam materi pelatihan sudah dijelaskan kepada peserta tentang Aspek yang dinilai dari segi aspek non finansial adalah aspek pasar, aspek pemasaran, aspek teknis dan teknologi, aspek manajemen dan SDM dan aspek lingkungan. Sementara dari aspek finansial dilihat dari payback period, net present value, profitability index dan internal rate of return.

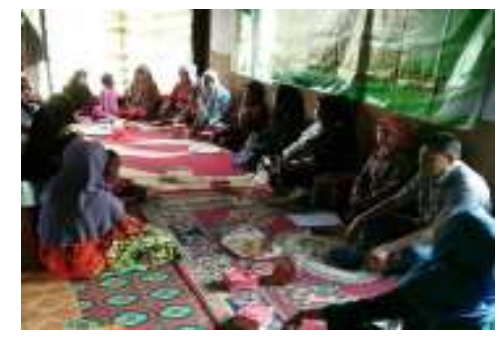

Mitra sasaran sebagian besar yaitu $65 \%$ dapat memahami faktor-faktor yang harus diperhatikan dalam menyusun analisis usaha.

Evaluasi berikutnya dilaksanakan setelah kegiatan pemberian keterampilan kepada khalayak berupa pelatihan menyusun analisis usaha kuliner makanan ringan.

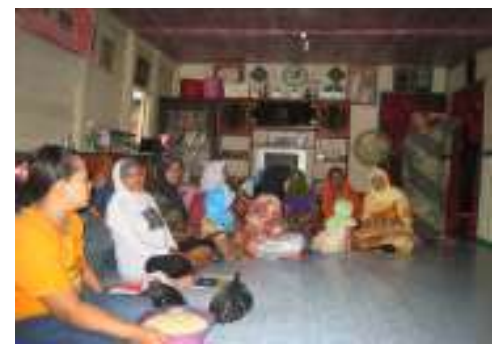

Berdasarkan hasil pelatihan dalam menganalisis usaha pada aspek pasar dapat disimpulkan peluang usaha melakukan produksi kue kering masih terbuka lebar. Alasannya karena sedikitnya jumlah pengusaha kue kering di wilayah tersebut, menyebabkan rendahnya tingkat persaingan sehingga harga jual relatif stabil. Meningkatnya penghasilan masyarakat menyebabkan kemungkinan peningkatan permintaan terhadap kue kering sehingga usaha ini 
layak untuk dilaksanakan.

\section{KESIMPULAN}

Berdasarkan hasil pelatihan analisis kelayakan usaha yang telah dilakukan, maka dapat diperoleh kesimpulan sebagai berikut :

1. Berdasarkan penilaian dari aspek non finansial yang terdiri dari aspek pasar, aspek pemasaran, aspek teknis dan teknologi, aspek manajemen dan SDM serta aspek lingkungan, maka rencana usaha kuliner makanan ringan kue kering yang dilakukan ibu-ibu di desa Tatah Pemangkih Laut Kabupaten Banjar. Apabila usulan investasi dapat diterima dengan nilai profitability indeks $>1$.

Berdasarkan latihan hasil perhitungan nilai waktu uang pada tingkat bunga yang lebih tinggi dari 14\% : layak untuk dilaksanakan.

2. Berdasarkan aspek finansial dengan mempertimbangkan nilai payback period, net present value methode, profitability indeks, dan internal rate of return, maka rencana usaha kuliner makanan ringan kue kering layak untuk dilaksanakan.

\section{DAFTAR PUSTAKA}

Basuki, Aida Vitria dan Susiladewi, 2020, Memberdayakan Masyarakat Desa Melalui Pemberian Keterampilan Dan Pendampingan Perubahan Sikap, Jurnal Al Ikhlas, Volume 5 No.2, halaman 182-187.

Ibrahim, Yacob. 2013. Studi Kelayakan Bisnis. Jakarta : Rineka Cipta.

Kamaluddin, 2004. Studi Kelayakan Bisnis. Malang: DIOMA

Kasmir dan Jakfar. 2004. Studi Kelayakan Bisnis. Jakarta: Kencana

Khumalasari, "Home Industri" media online, diakses tanggal 3 Februari 2015 dari https://arumdyankhumalasari.wor dpress.com/2011/04/16/homeindustril

Rangkuti, Freddy. 2012. Studi Kelayakan Bisnis Dan Investasi. Jakarta : PT. Gramedia Pustaka Utama.

Ratnasari, Suhono, Selvi, Evi, 2018, Analisis Kelayakan Usaha Peternakan Ayam Probiotik Pada PT. Gunung Mas, Jurnal Ekonomi dan Bisnis, Vol. 8 No. 1, Halaman $1-7$.

Suliyanto. 2010. Studi Kelayakan Bisnis. Yogyakarta : Penerbit ANDI.

Umar, Husein. 2013. Studi Kelayakan Bisnis. Jakarta : PT Gramedia Pustaka Utama.

Widyanti, Rahmi; Susiladewi dan Alfisah, Erni, 2020, Analisis Usaha Industri Rumah Tangga Melalui Pengolahan Kue Kering, Jurnal Al Ikhlas, Volume 5, No.2, halaman 176-181 